УДК 347.732

DOI https://doi.org/10.51989/NUL.2021.6.3

\title{
СТРАХОВИЙ РИНОК ЯК СФЕРА ДІЯЛЬНОСТІ НЕБАНКІВСЬКИХ ФІНАНСОВИХ УСТАНОВ
}

\author{
Буга Ганна Сергіївна, \\ ORCID: 0000-0003-3957-7387 \\ кандидат юридичних наук, доцент, \\ доцент кафедри адміністративно-правових дисциплін факультету № 2 \\ Донецького державного університету внутрішніх справ
}

Страховий ринок - це система економічних відносин щодо купівлі-продажу специфічного товару - страхового покриття внаслідок настання певних подій (страхових випадків), визначених договором страхування або чинним законодавством. В усіх економічно розвинутих країнах страхова діяльність $\epsilon$ однією з найважливіших галузей, що забезпечує дієвий захист соціальних і майнових інтересів фізичних та юридичних осіб від різноманітних ризиків, підтримання стабільності суспільства та економічної безпеки держави. Крім того, страхування є важливим фінансовим інструментом регулювання національної економіки та потужним засобом акумулювання коштів для їх подальшого інвестування в економіку. Світовий досвід переконливо доводить, що досконала система страхового захисту є основою забезпечення більш високого рівня стабільності економічного відтворювального процесу, досягнення соціальної злагоди, гарантом високого рівня життя населення. Створення дієвої системи захисту інтересів громадян, підприємців, держави, підтримання соціальної стабільності суспільства є неможливим без ефективного функціонування ринку страхових послуг. Держава, виходячи з економічної та соціальної ситуації, регулює розвиток страхового ринку країни. Проблема державного регулювання інституту страхування й участь у ньому небанківського сектору економіки є однією з найбільш актуальних у теорії та практиці сучасного вітчизняного страхування. Важливість ії дослідження пов'язана з тим, що ця система ще остаточно не сформувалася, адже змінюється стан самого страхового ринку, постійно вдосконалюється нормативна база страхування, зазнає змін діяльність органів державного регулювання й небанківських фінансових установ. Нестійкість системи страхового ринку викликана внутрішніми факторами та є наслідком макроекономічних процесів. Варто констатувати, що ключовою проблемою в здійсненні регулювання ринку фінансових послуг є недостатня координація дій між фінансовими регуляторами, що в процесі наглядової діяльності відображається в неузгодженості дій під час ухвалення нормативно-правових актів, а також під час недостатньої координації дій в умовах системних фінансових криз, недостатнього обміну інформацією та невідпрацьованості механізмів взаємодії під час нагляду за діяльністю фінансових конгломератів чи пов'язаних осіб. Вагоме значення також має подальша інтеграція України у світові структури, що визначають міжнародну політику в галузі регулювання фінансових послуг.

Ключові слова: небанківська фінансова установа, страхування, страховий ринок, страхова компанія.

\section{Buha Hanna. Insurance market as a sphere of activity of non-bank financial institutions}

The insurance market is a system of economic relations concerning the purchase and sale of a specific product - insurance coverage due to the occurrence of certain events (insured events), defined by the insurance contract or current legislation. The problem of state regulation of the insurance institution and the participation of the non-banking sector of the economy in it is one of the most relevant in the theory and practice of modern domestic insurance. The importance of its research is due to the fact that this system has not yet been fully formed, in particular: the state of the insurance market is changing, the regulatory framework of insurance is constantly improving, the activities of government regulators and non-bank financial institutions are changing. The instability of the system of state regulation of the insurance market is caused by internal factors of the insurance market, but at the same time is a direct consequence of macroeconomic processes, economic problems in general, as well as the development of international integration trends. 
A number of unresolved issues remain in the regulation of the domestic insurance market by insurance companies, in particular: insufficient coordination of actions of state bodies in charge of insurance issues, as well as state bodies and non-bank financial institutions, which leads to unsystematic decisions and reduced overall regulation of insurance activities; Insufficient powers of state bodies to apply sanctions and prosecute non-bank financial institutions for violations of insurance legislation, which does not increase the level of liability of professional participants in the insurance market; lack of a quality system of accounting, reporting, disclosure and supervision of insurance companies.

It should be noted that the key problem in the regulation of the financial services market is insufficient coordination between financial regulators, which in the process of supervisory activities is reflected in the inconsistency of their actions during the adoption of regulations, insufficient coordination in systemic financial crises, insufficient exchange information and lack of mechanisms for interaction during the supervision of financial conglomerates or related parties. The further integration of Ukraine into the world structures that determine the international policy in the field of financial services regulation is also important.

Key words: non-bank financial institution, insurance, insurance market, insurance company.

Страхування $€$ важливим елементом економічної безпеки як громадян, так і держави. у більшості країн світу система страхування фізичних і юридичних осіб $\epsilon$ врегульованою, однак дотепер розвивається, що не скажеш про страхову систему в Україні. Розвиток ринкових відносин викликав зміни в правовому житті населення. В Україні діє багато видів страхування, якими фізичні чи юридичні особи можуть скористатись на свій розсуд. Таке страхування $\epsilon$ необов'язковим. Однак $\epsilon$ обов'язкові види страхування, які зобов'язують особу виконати певні положення закону. Сучасний період економічного розвитку в Україні відбувається під знаком правової реформи, важливим аспектом якої $\epsilon$ забезпечення державою рівного захисту страховиків і страхувальників, визначення ефективних механізмів охорони їхніх прав та законних інтересів (завдяки заходам кримінально-правового впливу). Ухвалення низки нормативно-правових актів у нашій державі, беззаперечно, стало значним внеском у реалізацію цього завдання. Попри те, що в Україні $€$ досить значна кількість інститутів, які регулюють страхові правовідносини, вони не $є$ ефективними, а кількісний склад не переростає в якісний. Ухвалення Закону України «Про страхування» (1996 р.) створило правову базу для провадження діяльності страхових та перестрахових компаній, філій страховиків, товариств взаємного страхування, страхових та перестрахових посередників. Під час виходу української економіки зі стану депресії потреба в страховій та перестра- ховій діяльності зростатиме разом зі зростанням економіки [1].

В умовах функціонування ринкової економіки, основою якої $€$ господарська (підприємницька) діяльність із використанням різних форм власності, та механізму державного регулювання відносин у сфері економіки потреба суб'єктів господарської діяльності в захисті майнових прав й охоронюваних законом інтересів від різноманітних ризиків зростає. Нестійкість системи державного регулювання страхового ринку викликана внутрішніми факторами страхового ринку, а також $\in$ безпосереднім наслідком макроекономічних процесів, проблем економіки загалом та розвитку міжнародних інтеграційних тенденцій [2, с. 34].

Сучасний стан розвитку страхового ринку характеризується складністю та суперечністю, що пояснюється, на думку фахівців, недосконалістю галузевого законодавства, низькою платоспроможністю вітчизняних страхувальників, виявами галузевого монополізму, недостатнім рівнем кваліфікації кадрів у страхових компаніях, великою кількістю видів обов'язкового страхування, зловживаннями у сфері страхових відносин із боку як страховиків, так і страхувальників, що свідчить про необхідність удосконалення механізму адміністративно-правового регулювання.

Адміністративно-правове регулювання страхової діяльності спричинене також певними соціально-економічними потребами суспільства для мінімізації рівня ризику страховиків і страхувальників. 
Беручи до уваги комерційний інтерес страховиків над інтересами страхувальників, необхідність такого регулювання зумовлюється бажанням держави гарантувати соціальний спокій суспільству в умовах світової фінансової кризи.

Відмінною рисою українського законодавства $\epsilon$ те, що воно формується в умовах трансформаційної економіки та євроінтеграції, що впливає на інтенсивність розвитку законотворчого процесу i $\epsilon$ зумовленим потребами реформування суспільства, його переходом до ринкової економіки та розбудовою правової держави. Українське законодавство на цьому етапі $\epsilon$ складним багатогалузевим утворенням, у якому перетинаються вертикальні та горизонтальні зв'язки, діють законодавчі масиви різних рівнів. Нині правове регулювання організації та здійснення діяльності у сфері страхування характеризується наявністю як значних прогалин, так і колізій між правовими нормами [2].

Зміни, що відбуваються в Україні, яка прагне стати на шлях економічного зростання, $\epsilon$ неможливими без посилення уваги до інституту страхування. За сучасних умов ця сфера правовідносин набуває актуальності як галузь цивільного права, оскільки стає універсальним засобом захисту інтересів громадян і суб'єктів господарювання.

Із набуттям Україною незалежності ситуація на страховому ринку різко змінилася, зважаючи на демонополізацію страхової справи, легалізацію підприємств, у результаті чого відбулося збільшення кількості альтернативних недержавних комерційних страхових організацій, діяльність яких охопила, окрім історично сформованих видів страхування, страхування комерційних, фінансових, господарських ризиків, ризиків відповідальності за нанесення шкоди на території інших держав, експортних кредитів та іноземних інвестицій.

На думку фахівців, сьогодні в Україні формується нова галузь (страхова індустрія), призначена для надання широкого спектра послуг як юридичним особам різної форми власності, так і безпосередньо громадянам [3, с. 11].

Слово «страхування» ввійшло в українську мову давно. Воно має аналоги в інших мовах: «іnsurance» (англійська), «versicherungs» (німецька). Західні філологи вважають, що термін має латинське походження. В його основі лежить слово «securus», що дослівно означає «безтурботний» [4]. Отже, страхування відображає ідею застереження, захисту та безпеки.

Соціальна мета страхування полягає в охороні майнових інтересів від несприятливих обставин. За весь період розвитку суспільне виробництво наражається на суперечності між природою і людиною, а також між окремими суб'єктами виробничих відносин. Ці суперечності зумовлюють виникнення несприятливих подій (ризиків), як-от стихійні лиха і нещасні випадки. Потенційна можливість настання стихійних лих і нещасних випадків становить сутність страхового ризику. До страхових належать лише ті ризики, виникнення яких можна прогнозувати й оцінювати на підставі історичного досвіду та за допомогою математичних і статистичних методів [5, c. 12].

Страхування, будучи економічною категорією, перебуває в підпорядкованому зв'язку 3 категорією фінансів та $є$ сукупністю особливих перерозподільних відносин між його учасниками щодо формування за рахунок грошових коштів цільового страхового фонду, призначеного для відшкодування можливої шкоди $[6$, c. 18$]$.

Правова сутність страхування визначена в ст. 1 Закону України «Про страхування»: це вид цивільно-правових відносин щодо захисту майнових інтересів громадян та юридичних осіб у разі настання певних подій (страхових випадків), визначених договором страхування або законодавством, за рахунок грошових фондів, що формуються через сплату громадянами та юридичними особами страхових платежів [7]. Цей Закон охоплює права й обов'язки учасників страхових відносин. Ними $€$ страховики та страхувальники, а також інші фізичні та юридичні особи, як-от одержувачі страхового відшкодування, страхові посередники, державні регулятори та ін.

Страховий ринок - це система економічних відносин щодо купівлі-продажу специфічного товару - страхового покриття 
внаслідок настання певних подій (страхових випадків), визначених договором страхування або чинним законодавством. За територіальною ознакою виділяють місцевий (регіональний), національний (внутрішній) і світовий (зовнішній) страхові ринки; за галузевою - ринки особистого та майнового страхування. Кожна з цих ланок має свою структуру (сегментацію) [8].

За формою страхування може бути обов'язковим і добровільним. Добровільним $€$ страхування, яке здійснюється на основі договору між страхувальником і страховиком. Загальні умови й порядок здійснення добровільного страхування визначають правилами страхування, які встановлює страховик відповідно до вимог законодавства.

Видами добровільного страхування $\epsilon$ особисте страхування (страхування життя, страхування від нещасних випадків, страхування здоров'я), страхування засобів транспорту (наземного, повітряного, водного), страхування вантажів та багажу, страхування іншого майна, страхування відповідальності власників транспортних засобів, страхування кредитів, інвестицій, фінансових ризиків тощо. Предметом договору страхування (ст. 980 ЦК України) $€$ майнові інтереси, що не суперечать закону й пов'язані з життям, здоров'ям, працездатністю і пенсійним забезпеченням (особисте страхування); володінням, користуванням і розпоряджанням майном (майнове страхування); відшкодуванням шкоди, завданої страхувальником (страхування відповідальності).

Аналіз кількісних і якісних характеристик страхового ринку в Україні свідчить про позитивні тенденції в його розвитку.

Відбувся бурхливий розвиток інфраструктури страхування: збільшилася кількість суб'єктів ринку (страхові компанії, страхові посередники, страхові групи), пожвавилася взаємодія вітчизняного страхового ринку з міжнародним співтовариством (кількість страхових компаній з іноземним капіталом за період 2015-2020 pр. збільшилася майже вдвічі). Сьогодні основний сегмент страхового ринку України становить майнове страхування («Property insurance», «Non-life») - галузь, у якій об'єктом страхування $€$ майнові інтереси, пов'язані 3 володінням, розпорядженням та користуванням майном, а також випадки, коли ризик пов'язаний із втратою майна (90,5\% сукупного валового доходу від виплачених страхових премій).

Отже, розвиток страхового ринку важливий чинник становлення вітчизняної економіки. Доступні та вигідні умови страхування створюють підґрунтя для вчинення злочинів із метою незаконного одержання страхових виплат, унаслідок чого цей сегмент фінансового ринку останніми роками став одним із найбільш привабливих для активності шахраїв. Структура злочинів на ринку страхування визначається широким колом кримінально караних діянь, які посягають на різні об'єкти кримінально-правової охорони. Поряд зі злочинами у сфері господарської діяльності особливе місце в цій системі посідають різні види розкрадань, як-от шахрайство з боку професійних учасників страхового ринку (страховиків) і страхувальників.

Як зазначає С.С. Осадець, «страхування - це двосторонні правовідносини, які полягають у тому, що страхувальник, сплачуючи грошовий внесок, забезпечує собі (третій особі) у разі настання події, зумовленої договором або законом, суму виплати з боку страховика, який утримує певний обсяг відповідальності і для iї забезпечення поповнює та ефективно розміщує резерви, вживає превентивних заходів, спрямованих на зменшення ризику, а також перестраховує частину своєї відповідальності (за потреби)» [3, c. 34].

У визначенні сутності страхування особлива увага зосереджується на характеристиці його функцій, що виявляються безпосередньо в системі страхових правовідносин. Аналізуючи позицію вчених та досліджуючи практику страхової справи, виокремлюють такі функції страхування, що розкривають зміст страхування як економіко-правової категорії:

- запобігання - страхові ресурси можуть бути використані для заходів, спрямованих на запобігання можливих втрат страхувальників;

- відновлення - часткове або повне (залежно від умов договору) погашення втрат страхувальників; 
- збереження - використання страхових платежів як засобу нагромадження;

- контроль - страхові платежі акумулюються в страхові фонди на визначені цілі, вони мають використовуватися лише в конкретних випадках і лише визначеним колом суб'єктів, що беруть участь у формуванні страхових резервів;

- інвестиційна - розміщення страховиками тимчасово вільних грошових коштів страхових фондів у цінні папери, депозити банків тощо [9, с. 39].

У розвинутих країнах світу страхування, будучи інструментом державного регулювання, використовується за декількома напрямами. Зокрема, розвинутий страховий ринок створює одну з основ стійкого розвитку економіки, що дає змогу знизити бюджетні видатки в разі настання збитків не тільки природно-техногенного, а й соціально-економічного характеру в частині соціального забезпечення (пенсійні виплати, допомога у разі втрати працездатності або смерті годувальника, оплата медичних витрат тощо) [10, с. 37; 11, с. 57].

Роль страхування особливо важлива в контексті економічних реформ, оскільки воно стимулює розвиток ринкових відносин і ділової активності, поліпшує інвестиційний клімат. 3 огляду на це, можна зробити висновок, що ступінь розвитку страхового ринку свідчить про рівень економічного розвитку країни.

На думку В.С. Парнюк, зростання страхових капіталів робить так, що страхові установи непомітно перетворюються на кредитні установи, які відіграють важливу роль на страховому ринку [12, с. 10]. А.А. Гвозденко [13] зазначає, що ознаки кредитної категорії страхування знаходять конкретний вияв у функціях страхування:

- заощаджувальній

(страхування додаткової пенсії, ануїтет, страхування життя тощо);

- накопичувальній (страхування на дожиття, до весілля, ритуальне тощо);

- споживчій (придбання предметів довгострокового використання, отримання позик тощо);

- інвестиційній (вкладання коштів у прибуткові заходи, цінні папери тощо).

Удавану подібність із відносинами кредитування страхуванню надає така ознака, як зворотність страхових платежів. Проте вона стосується лише страхування життя, за якого більша частина внесків (неттоплатежі) повертається в разі настання страхового випадку (дожиття застрахованого до певного строку чи в разі його смерті). Але в разі майнового страхування страховані від нещасних випадків та інших видів страхування виплати страхового відшкодування можливі лише за умов настання страхового випадку і в розмірах, зазначених у договорі. Економічний зміст цих виплат відрізняється від повернення страхових платежів.

Висловлюється також думка А.А. Гвозденка про те, що нова роль страхових компаній полягає в тому, що вони все більше виконують функції спеціалізованих кредитних інститутів, опосередковано кредитуючи певні сфери і галузі господарської діяльності [13, с. 15].

Водночас, як підкреслив С С. Осадець, останнім часом дослідники під впливом західної теорії вдаються до розширеного тлумачення фінансів, виокремлюючи п'ять великих сфер їх функціонування: державні, галузеві, кредит і грошовий обіг, ринок цінних паперів, страхування $[3$, с. 26]. Ця концепція надає фінансам широкого змісту, який виводить їх далеко за межі розподільної категорії. У цьому контексті страхування стає на один рівень із кредитом, державними фінансами, фінансами галузей, фондовим ринком.

Таким чином, страхування органічно вписується в усі блоки фінансів, а страховики виробляють специфічні страхові послуги, розподіляють грошові кошти, беруть участь в обмінних процесах, а також певною мірою забезпечують виробниче і споживче споживання. Отже, з огляду на його функціональне призначення, страхування належить до стадій виробництва, розподілу, обміну й споживання. Без нього неможливо ефективно забезпечувати безперервність процесу виробництва матеріальних благ, підтримувати належний рівень життя людей.

3 огляду на ризикове функціонування будь-якої небанківської фінансової установи, концентрацію виробництва та ускладнення його технологій, ризики, пов'язані зі стихійними та техногенними аваріями та ризиковим середовищем 
проживання кожної людини, що постійно зростає, можна передбачити, що з кожним роком роль страхування в Україні в захисті економіки та життя людей буде швидко зростати. А якщо до цього додати державні пріоритети з переорієнтації програм соціального захисту громадян (охорона здоров'я, пенсійне страхування) на страхові засади, як це зроблено в країнах із ринковою економікою, то перспектива посилення ролі страхування в системі соціального захисту стає очевидною [14, с. 34].

Таким чином, страховий ринок - це система економічних відносин щодо купівліпродажу специфічного товару - страхового покриття внаслідок настання певних подій (страхових випадків), визначених договором страхування або чинним законодавством. У територіальному аспекті виокремлюють місцевий (регіональний), національний (внутрішній) та світовий (зовнішній) страхові ринки. За галузевою ознакою виокремлюють ринки особистого та майнового страхування. Кожна з цих ланок має свою структуру (сегментацію). За сучасних умов сфера страхування охоплює всі сторони виробничого й соціально-економічного життя суспільства, виконуючи такі функції, як захист майнових інтересів фізичних та юридичних осіб; створення нових механізмів фінансування; мінімізація причин та наслідків настання страхових випадків; сприяння захисту національних інтересів; стимулювання розвитку підприємництва та окремих його галузей; забезпечення захисту інтересів осіб у системі відносин цивільно-правової відповідальності; звільнення державного бюджету від додаткових фінансових видатків; збільшення інвестиційної привабливості суб'єктів господарювання та держави загалом.

Проблема державного регулювання інституту страхування й участь у ньому небанківського сектору економіки $є$ однією з найбільш актуальних у теорії та практиці сучасного вітчизняного страхування. Важливість ії дослідження пов'язана з тим, що ця система дотепер остаточно не сфор- мувалася, адже змінюється стан самого страхового ринку, постійно вдосконалюється нормативна база страхування, зазнає змін діяльність органів державного регулювання й небанківських фінансових установ. Нестійкість системи державного регулювання страхового ринку викликана внутрішніми факторами страхового ринку, а також $€$ наслідком макроекономічних процесів, проблем економіки загалом і розвитку міжнародних інтеграційних тенденцій.

У регулюванні вітчизняного страхового ринку, що здійснюється страховими компаніями, залишається низка невирішених проблем, як-от: недостатня узгодженість дій державних органів, що опікуються питаннями страхування, а також державних органів і небанківських фінансових установ, що призводить до безсистемних рішень і зниження загального рівня регулювання страхової діяльності; недостатній обсяг повноважень державних органів щодо застосування санкцій та притягнення до відповідальності небанківських фінансових установ за порушення страхового законодавства, що не сприяє підвищенню рівня відповідальності професійних учасників страхового ринку; відсутність якісної системи обліку, звітності, розкриття інформації та нагляду за діяльністю страхових організацій.

Варто констатувати, що ключовою проблемою в здійсненні регулювання ринку фінансових послуг $\epsilon$ недостатня координація дій між фінансовими регуляторами, що в процесі наглядової діяльності відображається в неузгодженості дій під час ухвалення нормативно-правових актів, а також у разі недостатньої координації дій в умовах системних фінансових криз, недостатнього обміну інформацією та невідпрацьованості механізмів взаємодії під час нагляду за діяльністю фінансових конгломератів чи пов'язаних осіб. Вагоме значення також має подальша інтеграція України у світові структури, що визначають міжнародну політику в галузі регулювання фінансових послуг.

\section{ЛITEPATУРА:}

1. Пацурія Н.Б. Войцеховська І.М., Головачова А.С. Правове регулювання діяльності у сфері страхування та перестрахування: проблеми теорії та практики : монографія. Київ : Вид-во Ліра-К, 2017. 256 с. 
2. Андрущенко Л.В. Державно-правове регулювання страхування у сфері зовнішньоекономічної діяльності : дис. ... канд. юрид. наук : 12.00.07. Київ, 2008. 220 с.

3. Страхування: підручник / кер. авт. кол. С.С. Осадець. Вид. 3-ге, перероб. і доп. Київ : KHEY, 2012. 599 c.

4. Журавка О.С., Бухтіарова А.Г., Пахненко О.М. Страхування: навчальний посібник. Суми : Сумський державний університет, 2020. 350 с.

5. Чайкін І.Б. Правове регулювання страхування ризиків на ринках фінансових послуг : автореф. дис. ... канд. юрид. наук : 12.00 .04 «Господарське право, господарсько-процесуальне право». Харків, 2007. 20 с.

6. Пацурія Н.Б. Страхове право України : навчальний посібник. Київ, 2006. 176 с.

7. Про страхування : Закон від 7 берез. 1996 р. № 85/96-BP. Верховна Рада України. URL: https://zakon.rada.gov.ua/laws/show/85/96-\%D0\%B2\%D1\%80\#Text

8. Страховий ринок України: стан та перспективи розвитку / С.О. Булгакова, А.В. Василенко, Л.І. Василенко та ін. ; за заг. ред. А.А. Мазаракі. Київ, 2007. 459 с.

9. Яворська Т.В. Страхові послуги : навчальний посібник. Львів, 2008. 250 с.

10. Нагайчук Н.Г., Гончаренко О.О. Фінанси страхових компаній : навчальний посібник. Київ : УБСНБУ, 2010. 585 с.

11. Бондар О.В., Залєтов О.М., Фурсевич П.В. Обов'язкове страхування. Київ : BeeZone, 2005. 496 c.

12. Парнюк В. Про деякі актуальні питання розвитку страхування в Україні. Економіка України. 2009. № 8. С. 10-15.

13. Гвозденко А.А. Основы страхования: учебник. Москва : Финансы и статистика, 2000. $304 \mathrm{c}$.

14. Мних М.В. Страхування в Україні в умовах економічної кризи. Інвестиції: практика та досвід. 2009. № 4. С. 34-35.

15. Фурман В.М. Страхування та його роль в соціально-економічних процесах. Фінанси України. 2005. № 8. С. 145-149. 